\section{HCV cache: the list}

\section{By Michael J. Haas, Senior Writer}

Researchers at The Scripps Research Institute have used a cell-based model of HCV infection to identify compounds on the market or in development for other indications that could be repurposed to treat HCV. ${ }^{1}$ But if repurposing the molecules is not feasible, the scaffolds of those compounds could serve as the basis of new HCV therapies.

Standard therapy for HCV infection includes a 48-week course of pegylated interferon- $\alpha$ (PEG-INF- $\alpha$ ) and ribavirin for HCV genotype 1 or a 24 -week course of the two drugs for genotypes 2 and 3. The regimen only works in $50 \%-60 \%$ of patients and causes a host of side effects.

Because of these shortcomings, Scripps researchers set about looking for new therapeutics that might be able to treat HCV. The group screened 446 compounds from a clinical collection at the NIH. The researchers used a human cell-based model of HCV infection that was developed at Scripps in 2005 and reproduces the virus' entire life cycle. ${ }^{2}$

The group found 33 compounds that had low micromolar to sub-micromolar activity against HCV. Of those, 26 are marketed, approved or in clinical development to treat a range of indications outside HCV (see Table 1, "HCV cache").

The team selected the 12 molecules with the best therapeutic indices and studied their modes of action. Most were inhibitors of viral entry, viral RNA replication or virion assembly.

The results were published in the Proceedings of the National Academy of Sciences. The group was led by Francis Chisari, professor of immunology and microbial science, who also headed the Scripps team that had developed the HCV infection model.

"We are very much interested in exploring any opportunities to repurpose existing drugs for $\mathrm{HCV}$ infection, and we routinely screen our entire compound collection" for potential hits, said Andrew Spaltenstein, VP of hepatitis C drug discovery at GlaxoSmithKline plc. However, he cautioned that repurposing may be complicated by differences in dosing.

Spaltenstein noted that the anti-HCV potencies for most of the compounds identified in the PNAS study were in the micromolar range, whereas the drugs' potencies against targets in their approved indications were greater by several orders of magnitude.

"This means that the required plasma concentrations for efficacy against HCV would massively exceed the exposures found safe and effective for the original purpose" and could lead to undesirable onand off-target effects, Spaltenstein said.

Indeed, one of the most clinically advanced new HCV therapies in development, the small molecule HCV NS3 protease inhibitor telaprevir (VX-950; MP-424), has an in vitro activity against HCV activity of $354 \mathrm{nM}$ (ref. 3) - greater by several orders of magnitude than most of the compounds identified by the Scripps team. Partners Vertex Pharmaceuticals Inc., Mitsubishi Tanabe Pharma Corp. and Johnson \& Johnson have telaprevir in Phase III testing to treat HCV infection.

In the PNAS paper, the Scripps team did raise the dosing issue specifically, saying more information than in vitro potency was "necessary before concluding that these compounds can be used to treat $\mathrm{HCV}$ infection in vivo."

\section{Issues beyond dosage}

Repurposing specific compounds for HCV might involve additional challenges such as drug delivery and resistance.

According to Spaltenstein, some of the drugs identified in the PNAS article may not come with appropriate routes of administration for HCV. A case in point, he said, was salmeterol, an adrenergic receptor $\beta_{2}(\mathrm{ADRB} 2)$ agonist that was among the hits. GSK markets Advair, an inhaled combination of salmeterol and fluticasone, to treat asthma and chronic obstructive pulmonary disease (COPD).

"Because Advair was optimized and developed as an inhaled agent, the pharmacokinetic properties of salmeterol are not favorable for use as a systemic agent and would likely have to be re-engineered" to target HCV in the liver, Spaltenstein told SciBX.

Drug resistance also could be a barrier to repurposing. Spaltenstein noted that drugs in widespread use for other indications have probably been taken by many HCV carriers. As a result, those patients might already harbor drug-resistant HCV. "Such HCV patients would then not respond to the repurposed drug to treat their infection," he said.

Similarly, an antiviral repurposed to treat HCV could induce drug resistance in its approved indication. For example, the PNAS study found that Pfizer Inc.'s HIV protease inhibitor Viracept nelfinavir had anti$\mathrm{HCV}$ activity. "But if nelfinavir were administered to an HCV patient who was unknowingly co-infected with HIV, then there would be a high likelihood for nelfinavir-resistant HIV to emerge-eliminating an important HIV treatment option for this patient," said Spaltenstein.

He added that GSK would remain open to the possibility of repurposing its drugs, but "at least after an initial analysis, I think chances are low that, in the end, the GSK drugs mentioned in the PNAS article will be suitable for repurposing for HCV."

Concurrent with its acquisition of Genelabs Technologies Inc. in January 2009, GSK created an R\&D unit that focuses on the discovery and early preclinical development of therapies to treat HCV infection. "We are poised to progress multiple assets into preclinical and clinical 
development in 2010," Spaltenstein said, but he declined to disclose specific compounds or targets.

\section{Finding a mechanism}

Repurposing hurdles aside, Spaltenstein said the screening study described in the PNAS paper could be a starting point for identifying new HCV targets and developing new anti-HCV scaffolds, much as cyclosporine did for HCV in the 1990s.

Long known as an immunosuppressant, cyclosporine's anti-HCV activity prompted many companies to discover "potent drugs that lack the immunosuppressive action of cyclosporine but retain its anti-HCV activity," Spaltenstein noted.

Table 1. HCV cache. A cell-based screen of over 400 molecules identified 26 compounds with low micromolar to submicromolar activity against $\mathrm{HCV}$ that are marketed, approved or in clinical development for other indications. Results were reported in the Proceedings of the National Academy of Sciences.

\begin{tabular}{|c|c|c|c|}
\hline Product name & Mechanism & Company & Status/Indication \\
\hline AcipHex rabeprazole & Proton pump inhibitor & $\begin{array}{l}\text { Eisai Co. Ltd./Johnson \& } \\
\text { Johnson }\end{array}$ & $\begin{array}{l}\text { Marketed for gastric ulcers and gastroesophageal reflux } \\
\text { disease (GERD) }\end{array}$ \\
\hline Alinia nitazoxanide & $\begin{array}{l}\text { Pyruvate ferredoxin } \\
\text { oxidoreductase inhibitor }\end{array}$ & Romark Laboratories L.C. & $\begin{array}{l}\text { Marketed for diarrhea associated with Cryptosporidium or } \\
\text { Giardia infection; Phase III to treat Clostridium difficile- } \\
\text { associated disease (CDAD); Phase II for HCV infection } \\
\text { and Crohn's disease }\end{array}$ \\
\hline Astepro/Optivar azelastine & $\begin{array}{l}\text { Histamine } \mathrm{H} 1 \text { receptor }(\mathrm{HRH} 1) \\
\text { antagonist }\end{array}$ & Meda AB & $\begin{array}{l}\text { Marketed as Astepro for allergic rhinitis; marketed as } \\
\text { Optivar for allergic conjunctivitis }\end{array}$ \\
\hline Clarinex/Aerius desloratadine & HRH1 antagonist & Merck \& Co. Inc. & Marketed for rhinitis and chronic idiopathic urticaria (CIU) \\
\hline Corlux mifepristone & $\begin{array}{l}\text { Progesterone receptor and } \\
\text { cortisol receptor GR-2 antagonist }\end{array}$ & Corcept Therapeutics Inc. & Phase III for depression and Cushing's disease \\
\hline Fareston toremifene & $\begin{array}{l}\text { Nonsteroidal selective estrogen } \\
\text { receptor modulator (SERM) }\end{array}$ & $\begin{array}{l}\text { GTx Inc./Ipsen Group/ } \\
\text { Orion Corp. }\end{array}$ & $\begin{array}{l}\text { Marketed for breast cancer; in registration to reduce } \\
\text { fractures in men with prostate cancer; Phase III to prevent } \\
\text { prostate cancer }\end{array}$ \\
\hline Gleevec/Glivec imatinib & $\begin{array}{l}\text { BCR-ABL tyrosine kinase } \\
\text { inhibitor }\end{array}$ & Novartis AG & $\begin{array}{l}\text { Marketed for acute lymphoblastic leukemia (ALL), chronic } \\
\text { myelogenous leukemia (CML), gastrointestinal stromal } \\
\text { tumors (GIST) and hematological malignancies }\end{array}$ \\
\hline Haldol haloperidol & Butyrophenone antipsychotic & Johnson \& Johnson & Marketed for schizophrenia and Tourette syndrome \\
\hline Mycobutin rifabutin & Antibiotic & Pfizer Inc. & $\begin{array}{l}\text { Marketed to prevent disseminated Mycobacterium } \\
\text { avium complex (MAC) disease }\end{array}$ \\
\hline Rimcazole & $\sigma-1$ Receptor agonist & Modern Biosciences plc & In-licensed by Modern for cancer \\
\hline Serevent salmeterol & $\begin{array}{l}\text { Adrenergic receptor } \beta_{2}(\mathrm{ADRB} 2) \\
\text { agonist }\end{array}$ & GlaxoSmithKline plc & $\begin{array}{l}\text { Marketed for asthma and chronic obstructive pulmonary } \\
\text { disease (COPD) }\end{array}$ \\
\hline Silenor doxepin & HRH1 antagonist & Somaxon Pharmaceuticals Inc. & $\begin{array}{l}\text { In registration for insomnia; available as a generic to treat } \\
\text { depression }\end{array}$ \\
\hline Staccato prochlorperazine & $\begin{array}{l}\text { Dopamine } \mathrm{D} 2 \text { receptor } \\
\text { antagonist }\end{array}$ & Alexza Pharmaceuticals Inc. & $\begin{array}{l}\text { Phase II with Alexza's proprietary Staccato system inhaler } \\
\text { to treat migraine; available as a generic to treat nausea and } \\
\text { vertigo }\end{array}$ \\
\hline Viracept nelfinavir & HIV protease inhibitor & Pfizer/Roche & Marketed for HIV/AIDS \\
\hline Amiodarone & Antiarrhythmic agent & Generic & Fibrillation and tachycardia \\
\hline Benproperine $^{A}$ & Information not available & Information not available & Cough \\
\hline Calcipotriol & Information not available & Generic & Psoriasis \\
\hline Carvedilol & $\begin{array}{l}\text { Adrenergic receptor } \beta_{1} \text { (ADRB1) } \\
\text { and ADRB2 antagonist }\end{array}$ & Generic & Heart failure, hypertension and myocardial infarction (MI) \\
\hline Cyproheptadine & $\begin{array}{l}\text { Serotonin }\left(5-\mathrm{HT}_{1}\right) \text { receptor } \\
\text { antagonist }\end{array}$ & Generic & Allergy and hay fever \\
\hline Fluphenazine & Phenothiazine antipsychotic & Generic & Schizophrenia and bipolar mania \\
\hline Ketotifen & $\begin{array}{l}\text { Second-generation } \mathrm{H} 1 \\
\text { antihistamine/mast cell stabilizer }\end{array}$ & Generic & Allergic conjunctivitis, asthma and itchy eyes \\
\hline Lacidipine $^{\mathrm{A}}$ & Calcium channel blocker & Information not available & Hypertension \\
\hline Lofepramine & Tricyclic antidepressant & Generic & Anxiety, depression and other neurological indications \\
\hline Paroxetine & $\begin{array}{l}\text { Selective serotonin reuptake } \\
\text { inhibitor (SSRI) }\end{array}$ & Generic & Anxiety, depression and other neurological indications \\
\hline Pizotyline $^{\mathrm{A}}$ & $\begin{array}{l}\text { Serotonin }\left(5-\mathrm{HT}_{1}, 5-\mathrm{HT}_{2 \mathrm{~A}} \text {, }\right. \\
\left.5-\mathrm{HT}_{2 \mathrm{C}}\right) \text { receptor antagonist }\end{array}$ & Information not available & Migraine \\
\hline Trifluoperazine & Phenothiazine antipsychotic & Generic & Schizophrenia \\
\hline
\end{tabular}

${ }^{A}$ May not be currently available on the market. 


\section{ANALYSIS}

\section{TARGETS \& MECHANISMS}

Cyclosporine's activity against HCV was first observed in posttransplant patients who experienced exacerbations in their $\mathrm{HCV}$ infections when they stopped taking the drug as immunosuppressive therapy. ${ }^{4-6}$

Debiopharm S.A.'s Debio 025, a nonimmunosuppressive cyclosporine that targets cyclophilin, is in Phase II testing to treat $\mathrm{HCV}$ infection. At least two other companies have cyclophilin inhibitors in the clinic to treat HCV: Novartis AG's NIM811 is in Phase II testing and Scynexis Inc.'s SCY-635 has completed Phase I testing.

In addition, Spaltenstein thinks working out the mechanisms by which each compound in the PNAS article exerts its anti-HCV activity will be the key to finding "new anti-HCV targets and/or molecular drug scaffolds."

Indeed, on the heels of the work published in PNAS "additional studies by Dr. Chisari and his group revealed target molecules and mechanisms of antiviral actions for some of the compounds," said Linda Pullan, CEO of Viriome Inc., an antiviral company founded in 2007 by Chisari and Vincent Zurawski, president and CEO of neurology company Varinel Inc.

Pullan said that Scripps has filed provisional patents covering the findings of the PNAS paper and of the follow-on studies. Viriome has an exclusive option to license the IP.
The Scripps team was unavailable for comment.

Haas, M.J. SciBX 3(1); doi:10.1038/scibx.2010.3

Published online Jan. 7, 2010

\section{REFERENCES}

1. Gastaminza, P. et al. Proc. Natl. Acad. Sci. USA; published online Dec. 7, 2009; doi:10.1073/pnas.0912966107

Contact: Francis V. Chisari, The Scripps Research Institute, La Jolla, Calif. e-mail: fchisari@scripps.edu

2. Zhong, J. et al. Proc. Natl. Acad. Sci. USA 102, 9294-9299 (2005)

3. Perni, R. et al. Antimicrob. Agents Chemother. 50, 899-909 (2006)

4. Kanamori, H. et al. Am. J. Med. Sci. 303, 109-111 (1992)

5. Gruber, A. et al. J. Intern. Med. 234, 223-225 (1993)

6. Akiyama, H. et al. Bone Marrow Transplant. 20, 993-995 (1997)

\section{COMPANIES AND INSTITUTIONS MENTIONED}

Debiopharm S.A., Lausanne, Switzerland

Genelabs Technologies Inc. (NASDAQ:GNLB), Redwood City, Calif.

GlaxoSmithKline plc (LSE:GSK; NYSE:GSK), London, U.K.

Johnson \& Johnson (NYSE:JNJ), New Brunswick, N.J.

Mitsubishi Tanabe Pharma Corp. (Tokyo:4508; Osaka:4508), Osaka, Japan

National Institutes of Health, Bethesda, Md.

Novartis AG (NYSE:NVS; SIX:NOVN), Basel, Switzerland

Pfizer Inc. (NYSE:PFE), New York, N.Y.

The Scripps Research Institute, La Jolla, Calif.

Scynexis Inc., Research Triangle Park, N.C.

Varinel Inc., West Chester, $\mathrm{Pa}$.

Vertex Pharmaceuticals Inc. (NASDAQ:VRTX), Cambridge, Mass.

Viriome Inc., Newbury Park, Calif. 